\title{
Financial Security of Farmers through Homestead Vegetable Production in Barishal District, Bangladesh
}

\author{
Md. Kamruzzaman Suza, Shaikh Shamim Hasan, Mithun Kumar Ghosh, Md. Enamul Haque, \\ and Mursaleen Zebin Turin
}

\begin{abstract}
Homestead farming is always ignored though it is a boundless promising area for economic sustainability. Therefore, the present study was undertaken to determine the present status of the homestead vegetable production and also to ascertain the socio-economic condition of the local farmers of the Barishal District. The influence of different types of socioeconomic factors on the economic security of the farmers through homestead vegetable production was also investigated through this study. Following proportionate random sampling technique, a total number of $\mathbf{1 8 0}$ farmers were sampled from three villages of Babuganj Upazila of Barishal of Bangladesh and were interviewed through a predesigned questionnaire. The findings of the study revealed that half of farmers were more than 50 years old, of whom $89 \%$ were educated either primary to more than SSC level and had an average family annual income of USD 1967.9. The family size of the respondents indicated that $80 \%$ of the farmers had small to medium (4-6 members) family size. The findings also indicated that, on an average, the farmers had 1.25 acre of total land and 0.17 acre of homestead vegetable land in which they spent about 3 hours of time in a day to perform homestead vegetable production. Out of all the farmers, $30 \%$ of them didn't receive any training on any agriculture related issues and $30 \%$ of them didn't receive any training on homestead vegetable gardening related issues. The farmers of the study area practiced some technologies in homestead vegetable production, like, balanced fertilizer use, and pheromone trap. The farmers produced different types of vegetables in their homestead areas and among them green papaya, brinjal and tomato were the dominant. The results of the study also revealed that the farmers earned about USD 50 per year from homestead vegetable gardening which helped them to upsurge some sorts of financial safety and improve nutritional status of their families. In addition, out of nine attributes, two attributes, namely, family size and vegetable land ownership had significant influence on the financial security through homestead vegetable gardening.
\end{abstract}

Key words - Financial security, homestead, socio-economic, vegetable production.

\section{INTRODUCTION}

Bangladesh is predominantly an agricultural and highly populous (both no. and density) country [1]-[3] with the

Published on August 18, 2021.

Md. Kamruzzaman Suza, Dept. of Agricultural Extension and Rural Development, Bangabandhu Sheikh Mujibur Rahman Agricultural University, Bangladesh.

(e-mail: suzabsmrau2020@gmail.com)

Shaikh Shamim Hasan, Dept. of Agricultural Extension and Rural Development, Bangabandhu Sheikh Mujibur Rahman Agricultural University, Bangladesh.

(Corresponding e-mail: shamim.aer@bsmrau.edu.bd)

Mithun Kumar Ghosh, EXIM Bank Agricultural University Bangladesh, Bangladesh.

(e-mail: mithunbsmrau88@yahoo.com). sector accounting for $13.07 \%$ of the country's GDP and employing around $39.46 \%$ of the total labor force [4]. In spite of recurrent natural calamities, the country has achieved impressive gains in food grain production in the recent decades and reached to near self-sufficiency at the national level by producing nearly 347.1 lakh tons of rice in 2016 [5]. The food grain production in the country has increased by almost three times from 1970s [6]. The paucity of fertile cultivable land in Bangladesh is one of the biggest obstacles to achieving food security. Nearly a third of the 97.5 million rural households are landless, with no additional cultivable land beyond their homestead. The majority of the land accessible for cultivation is in small parcels, with over half of the population cultivating land of less than one hectare. Farmers who own land of one hectare or more account for the remaining $20 \%$ of the land. Furthermore, as a result of industrialization and population pressure, cultivable land is rapidly diminishing [6].

In spite of scarcity of land and the small size of land holding, the majority of rural households (including those considered functionally landless), usually have small plots of land next to their homesteads that have potential to grow essential commodities for their subsistence [7]. Homestead gardens are tiny plots of land surrounding a homestead, usually less than $500 \mathrm{~m}^{2}$, containing space for cattle, trees, and vegetable gardens [8]. Homestead-based interventions such as vegetable gardening have proven to be effective in alleviating poverty among resource-poor individuals in developing countries such as Bangladesh [6]. Smallholders, who occupy less than a quarter of a hectare of cultivated land and often practice intensive subsistence agriculture, account for more than $80 \%$ of the country's 14.7 million agriculture farm households [9]. They cultivate a diverse range of plant species (vegetables, fruits, medicinal plants, and trees), as well as animal and poultry buildings and fishponds [10], [11].

Home gardening or homestead gardening is an ancient method of food production that is commonly practiced throughout the world. Growing vegetables in the homestead is a traditional practice in Bangladesh, yet gardens often vary in size, biodiversity, and seasonal produce and are adapted to

Md. Enamul Haque, Dept. of Agricultural Extension and Rura Development, Bangabandhu Sheikh Mujibur Rahman Agricultural University, Bangladesh

(Corresponding e-mail: denamul_aer@bsmrau.edu.bd).

Mursaleen Zebin Turin, Bangladesh Institute of Research and Training on Applied Nutrition (BIRTAN), Bangladesh.

(e-mail: turinbsmrau ${ }^{@}$ gmail.com) 
local resources and cultural preferences [12]. An increase in the production and productivity of home gardens may be a viable alternative for providing food and ensuring economic security in poor households of Bangladesh. Although, at present, both vegetable production and consumption in Bangladesh is lesser than its neighboring countries [13].

Improved food security, increased food availability, and better nutrition through food diversity, income and expanded rural employment, reduced risk through diversification, and environmental advantages by recycling water and waste nutrients are all key benefits of home gardens [11], [14], [15]. The UN's Food and Agriculture Organization has extensively reported on their potential contributions to food security, income, and rural employment across Asia, including Bangladesh, Sri Lanka, India, Indonesia, and the Philippines, as well as beyond Asia [9].

Different studies have been conducted on the homestead vegetable gardening focusing mainly on food and nutritional security (like, [12], [16]-[19]. While some other studies (like, [20], [21] focuses on women employment and empowerment through homestead vegetable production. However, there is a dearth of research that put focus on the financial security of homestead vegetable production. That is why the main purposes of the present study are to explore the present status of homestead vegetable production in some selected areas of Bangladesh and how it affects rural peoples' financial aspect. Accordingly, with these views in mind, the present study was formulated mainly to determine the present status of homestead vegetable production and to ascertain the socio demographic characteristic of the respondents and explore their contribution on the financial security from vegetable production.

\section{MATERIALS AND METHODS}

The study was a descriptive survey research, designed to examine the impact of homestead vegetable production on financial security of vegetable growers and to ascertain the socio demographic characteristic of the respondents. We also ascertained the contribution of the selected characteristics of respondents on their financial security through homestead vegetable production. We took purposively selected three villages, namely, Rakundia, Rautkati, and Uttar Dehergati of Dehergati union of Babuganj upazila of Barisal district as the study area and collected desirable response from the respondents who were involved with homestead vegetable production. Meanwhile, we selected a total of 180 (15\% of the total population and 50, 78 and 52 farmers from Rakundia, Rautkati and Uttar Dehergati villages, respectively) vegetable farmers by proportionate random sampling technique. Then face-to-face personal interview was undertaken using the pre-structured interview schedule to collect relevant data from the respondents.

\section{A. Independent Variables and Their Measurement Technique}

We selected 10 independent variables for the study and measured those according to their nature:

1) Age of the respondents was measured in terms of years on the basis of his/her response. A score of one was assigned for each year of age.
2) We measured educational qualification of a respondent in terms of degree s/he obtained in formal education system (i.e., primary school, high school). A literacy score of 1 was given to a respondent who could sign his name reasonably assumed as an equivalent to class I. similarly, a respondent who could not read and write fall under can't read and write criteria with a score of 0 .

3) While, when family size was measured, we provided a score of 1 for each member of a household like husband, wife, children, and other members who were living together in a family.

4) Meanwhile, agricultural experience was operationalized by computing the total number of years of agriculture related experience of a respondent.

5) Accordingly, a score of 1 was provided to a respondent for every hour time spent in a day in homestead vegetable gardening by a respondent.

6) Total land holding is the aggregate of all areas (in terms of acre) holding by a farmer which included homestead area, own land under own cultivation, land taken from or given to others on lease, land taken from or given to others on lease, and it measured actual land ownership of a respondents in acre.

7) Consequently, homestead vegetable land holding was also calculated as total area of land of a respondent which was occupied with only vegetable cultivation, and it was also measured in acre.

8) Family annual income of a respondent was determined on the basis of his/her total earnings from different sources, like, agriculture, service, business and others. It was expressed in USD.

9) However, extension communication scores of the respondents were computed on the basis of their contact with different sources of extension information likely; contact with Sub Assistant Agriculture Officers (SAAOs), contact with seed dealers, contact with others of agricultural offices. To compute this variable, the respondents were asked how frequently they communicated with those extension media and put scores like, 4 for always, 3 for sometimes, 2 for occasionally and 1 for rarely.

10) Training received on agriculture was measured by the total number of days that a respondent had participated in different agriculture related training in his/her entire life from different GO/NGO organizations.

\section{B. Dependent Variable and It's Measurement Technique}

We grabbed two dependent variables for this study, that are, socioeconomic impact of homestead vegetable production and second one was the financial security of the respondents from homestead vegetable production. For recognizing the socioeconomic impact of homestead vegetable production, we asked the respondents to provide their opinion/response on some socioeconomic impact (08 aspects) of homestead vegetable production. Accordingly, socioeconomic impact of homestead vegetable production of the respondents was measured by constructing a 5-point (i.e., strongly agree, agree, undecided, disagree and strongly disagree) Likert type scale and the scoring were strongly agree (5), agree (4), undecided (3), disagree (2) and strongly disagree (1). The same type of measurement technique was followed by [22]-[26]. Then based on the average score, the 
socioeconomic impact of homestead vegetable production was arranged in rank order.

Meanwhile, the other dependent variable of this study was the financial security of the respondents from homestead vegetable production in the study area. The financial security is the ability of individuals, households, or communities to cover their essential needs sustainably and with dignity. In this specific study we determined the financial security by the respondents' income specifically from homestead vegetable production. It was calculated based on his or her total earnings from farming various homestead vegetable production during the preceding year (at the time of data collection and based on 2019 income). The income from homestead vegetable ranged from BDT 0 to USD 86.25 with an average of USD 49.28 and the respondents were classified into four categories (no income; USD $<12$; USD 12.1-25; and USD>25) based on their income from homestead vegetable production. The same categorization was also followed by [27], [28], [23].

\section{Multiple Linear Regression Procedure}

We used full-model regression analysis on eight independent variables (respondents age, educational qualification, family size, agricultural experience, family annual income, time in homestead gardening, training received on agriculture, extension communication, total land ownership, and vegetable land ownership) to determine the factors influencing respondents' financial security of the homestead vegetable production. Due to the nature of the dependent variable, we then performed the linear regression model. As a result, the latent equation (equation 1) used in this research was:

$\mathrm{y}=\beta \mathrm{o}+\beta_{1} \mathrm{x}_{1}+\beta_{2} \mathrm{x}_{2}+\ldots+\beta_{10} \mathrm{x}_{10}+\varepsilon$

where, $y$ was the dependent variable, $\beta 0$ was the intercept, $\beta 1$ 8 was the coefficient, and $\times 1-8$ was the independent variables.

The independent variables that influenced on the respondents' awareness to climate change were as follows:

$\mathrm{X}_{1}=$ Age of the respondents in years;

$\mathrm{X}_{2}=$ Educational qualification of the respondents in years;

$\mathrm{X}_{3}=$ Family size of the respondents in numbers;

$\mathrm{X}_{4}=$ Agricultural experience in years;

$\mathrm{X}_{5}=$ Family annual income of the respondents in USD;

$\mathrm{X}_{6}=$ Time spends in homestead gardening;

$\mathrm{X}_{7}=$ Training received on agriculture of the respondents;

$\mathrm{X}_{8}=$ Extension communication of the respondents;

$\mathrm{X}_{9}=$ Total land ownership of the respondents;

$\mathrm{X}_{10}=$ Vegetable land ownership of the respondents.

After gathering data from respondents in the study area, we categorized and classified the data according to the study's objectives. In addition, we used multiple regression analysis with significance levels of 0.10 , and 0.01 to estimate the impact of the attributes.

\section{RESULTS AND DISCUSSIONS}

\section{A. Personal Characteristics of the Respondents}

The age of the respondents ranged from 25 to 65 years (average of 49.42 years) indicated most of the respondents were near about older. Older people are less eager than young people for vegetable cultivation. Old aged people are less change oriented also try to follow traditional farming practices. The respondents' educational qualification ranged from can't read and write to above SSC level of education with the mean of 7.7. Through their study, [24] also found similar average level of education when they conducted their study with pineapple growers in Tangail district of Bangladesh. Education plays a significant role in facilitating awareness and reduces the amount of complexity perceived about a technology. The more educated farmers are expected to be more efficient to understand and obtain new technologies [29] and the vice-versa [30]. Findings from Table 1 indicated that the number of family members of the respondents ranged from 3 to 10 with an average of 4.73 . The results revealed that the average family size (4.73) of the respondents was higher than the national average (4.2) [4]. Agriculture experience is the farming experience of the respondents which ranged from 4 to 40 with an average of 18.43 years revealed that the respondents of the study area had relatively higher, i.e., 11 to more than 20 years of experience $(76.7 \%)$ in farming. It was due to the study area was a rural area where farming was the primary profession of the local people. Most of the people had been engaged in the farming operation since their childhood. [31] also found similar type of results in Jashore, Bangladesh as the farmers of that area also had 11 to more than 20 years of experience $(81 \%)$. The average family annual income of the respondents in the study area (USD 1967.9) was less than the national average (USD 1988.7) in the rural areas of Bangladesh [32]. Most of the respondents of study site engaged in farming profession who were poor in economic status. They hardly had the opportunity to shift their profession. Besides, poor communication network hampered their transportation of agro-products. Natural disasters made their life difficult which ultimately resulted in low family income.

Findings obtained from Table I revealed that the respondents spent 2 to 6 hours with an average of 3.13 hours per day in their homestead gardening. Majority of the respondents of the study area were rice grower. So, they put more emphasis on cereal crop production. But in recent years, promotion by the Department of Agricultural Extension (DAE) agents encouraged them to engage in homestead gardening. Women particularly spent more time in homestead vegetable production after carrying out their different household activities [33], [34].

In the study area the most percentage of respondents $(67.70 \%)$ received 1 to 3 training followed by the respondents with no training $(30 \%)$. This table revealed that a significant portion of the respondents $(70 \%)$ received training on agriculture-related issues. In the study area, agriculturerelated training programs were arranged by different GOs and NGOs. These programs helped the local people to improve their farming practices. Through training, they developed their skill in farming which in the end increase their production as well as their economic return. Moreover, Data furnished in the Table 1 also indicated that about $30 \%$ of the respondents did not receive any training on homestead vegetable production in the study area. Although, training exclusively on homestead vegetable gardening is crucial for uplifting the productivity of vegetables and helping to earn extra income from vegetable production. 
TABLE I: PERSONAL CHARACTERISTICS OF THE RESPONDENTS

\begin{tabular}{|c|c|c|c|c|}
\hline Characteristics & Categories & $\begin{array}{l}\text { Respondents } \\
(\%)\end{array}$ & $\begin{array}{l}\text { Observed } \\
\text { score }\end{array}$ & Mean \\
\hline Age & $\begin{array}{c}<30 \text { years } \\
31-40 \text { years } \\
41-50 \text { years } \\
>50 \text { years }\end{array}$ & $\begin{array}{c}3.30 \\
17.80 \\
28.90 \\
50.00\end{array}$ & $\begin{array}{l}25-65 \\
\text { years }\end{array}$ & 49.42 \\
\hline $\begin{array}{l}\text { Educational } \\
\text { qualification }\end{array}$ & $\begin{array}{c}\text { Cannot read \& } \\
\text { write } \\
\text { Primary } \\
\text { Secondary } \\
\text { SSC and } \\
\text { above }\end{array}$ & $\begin{array}{c}4.00 \\
16.00 \\
69.00 \\
11.00\end{array}$ & $0-13$ & 7.7 \\
\hline Family size & $\begin{array}{c}\text { Small (4) } \\
\text { Medium (5-6) } \\
\text { Large }(>6)\end{array}$ & $\begin{array}{l}64.40 \\
44.40 \\
32.20\end{array}$ & $3-10$ & 4.73 \\
\hline $\begin{array}{l}\text { Agricultural } \\
\text { experience }\end{array}$ & $\begin{array}{c}<10 \text { years } \\
11-20 \text { years } \\
>20 \text { years }\end{array}$ & $\begin{array}{l}23.30 \\
44.40 \\
32.30\end{array}$ & $\begin{array}{l}4-40 \\
\text { years }\end{array}$ & 18.43 \\
\hline $\begin{array}{c}\text { Family annual } \\
\text { income } \\
\text { (in USD) }\end{array}$ & $\begin{array}{c}<1250 \\
1251-2500 \\
2501-3750 \\
>3750\end{array}$ & $\begin{array}{c}28.90 \\
50.00 \\
4.40 \\
16.70\end{array}$ & $\begin{array}{c}\text { USD } \\
375-5875\end{array}$ & $\begin{array}{l}\text { USD } \\
1967.9\end{array}$ \\
\hline $\begin{array}{l}\text { Time spends in } \\
\text { homestead } \\
\text { gardening } \\
\text { (hours/day) }\end{array}$ & $\begin{array}{l}2-3 \text { hours } \\
4-5 \text { hours } \\
>5 \text { hours }\end{array}$ & $\begin{array}{c}67.80 \\
31.10 \\
1.10\end{array}$ & 2-6 hours & 3.13 \\
\hline $\begin{array}{l}\text { Training } \\
\text { received on } \\
\text { agriculture } \\
\text { Training on } \\
\text { homestead } \\
\text { vegetable } \\
\text { production }\end{array}$ & $\begin{array}{c}\text { No training } \\
\text { 1-3 training } \\
>3 \text { training } \\
\text { Receive } \\
\text { training } \\
\text { Do not receive } \\
\text { training }\end{array}$ & $\begin{array}{c}30.00 \\
67.70 \\
2.30 \\
\\
70.00 \\
30.00\end{array}$ & 1.64 & 1.96 \\
\hline $\begin{array}{c}\text { Extension } \\
\text { communication }\end{array}$ & $\begin{array}{c}\text { Always } \\
\text { Sometimes } \\
\text { Occasionally } \\
\text { Rarely }\end{array}$ & $\begin{array}{c}5.60 \\
5.60 \\
32.20 \\
56.60\end{array}$ & 1.61 & $1-4$ \\
\hline $\begin{array}{l}\text { Total land } \\
\text { ownership } \\
\text { (in acre) }\end{array}$ & $\begin{array}{c}\text { Landless } \\
(<0.05) \\
\text { Marginal } \\
(0.05-0.5) \\
\text { Small }(0.51- \\
2.47) \\
\text { Medium }(2.48 \\
-7.41)\end{array}$ & $\begin{array}{c}0.00 \\
31.10 \\
68.90 \\
0.00 \\
0.00\end{array}$ & $\begin{array}{c}0.42-2.46 \\
\text { acre }\end{array}$ & 1.25 \\
\hline $\begin{array}{l}\text { Vegetable land } \\
\text { ownership (in } \\
\text { acre) }\end{array}$ & $\begin{array}{c}\text { Large }(>7.41) \\
\text { No home. veg. } \\
\text { land } \\
0.01-0.05 \\
0.06-0.30 \\
>0.30\end{array}$ & $\begin{array}{c}4.5 \\
34.8 \\
44.9 \\
15.8\end{array}$ & 0-01 acre & 0.17 \\
\hline
\end{tabular}

Information contained in Table I exhibited that $56.6 \%$ of the respondents rarely communicated with any of the extension sources. It was followed by $32.2 \%$ respondents only occasionally communicated with extension sources and both $5.6 \%$ respondents always and sometimes communicated with different types of extension sources, respectively. Extension media communication pertains to one's contact with multifarious sources of knowledge and information. This results in a cognitive change of the users with an eventual change in attitude as well as behavior [26] and also in skill. Extension personnel regularly visited in the study area and provided different types of extension services to the farmers.

Land ownership is a major determining factor of the livelihood and socio-economic status of a rural household in Bangladesh [35]. The data revealed that average land size of the respondents was 1.25 acre which is not satisfactory. Land fragmentation, poverty, encroachment by influential people was the primary reasons behind their poor land holding. In addition, the Bangladeshi government has established significant policy thrust areas such as maximizing the use of accessible resources, capturing, and reversing degraded lands [25]. Majority of them were small farmers, who had less opportunity for homestead farming. The homestead vegetable land of the respondents ranged from 0 to 1 acre with an average of 0.17 acres which was less than the national average (1.97 acres) [36. This indicated that the farmland status of the respondents in the study area was a typical farming community of Bangladesh. Most of the respondents grew vegetables for their subsistence because it is very difficult to shift towards commercial farming with this inadequate land.

\section{B. Distribution of Different Vegetables Species according to Cropping Season}

The respondents of the study area grew different types of vegetables all the year round in their homestead areas. The respondents and their family members consumed these vegetables and also sold these into the market to earn money. Distribution of different types of vegetables of the study area was exhibited in Table II below:

TABLE II: DistRIBUTION OF DifFERENT TYPES OF VEGETABLES IN THE STUDY AREA (BASED ON 2019 DATA)

\begin{tabular}{|c|c|c|c|c|c|c|}
\hline $\begin{array}{l}\text { Cropping } \\
\text { season }\end{array}$ & Vegetables & $\begin{array}{l}\text { Average } \\
\text { production } \\
(\mathrm{kg})\end{array}$ & $\begin{array}{c}\text { Average } \\
\text { household } \\
\text { consumption } \\
(\mathrm{kg})\end{array}$ & $\begin{array}{l}\text { Average } \\
\text { Sold }(\mathrm{kg})\end{array}$ & $\begin{array}{l}\text { Average } \\
\text { Selling } \\
\text { price } \\
\text { (USD) } / \mathrm{kg}\end{array}$ & $\begin{array}{l}\text { Average } \\
\text { production } \\
\text { cost (USD) }\end{array}$ \\
\hline \multirow{6}{*}{ Summer } & Brinjal & 28.90 & 13.44 & 11.16 & 0.12 & 2.48 \\
\hline & Spinach & 18.61 & 4.84 & 12.47 & 0.10 & 0.74 \\
\hline & Bitter gourd & 22.63 & 6.34 & 14.26 & 0.18 & 3.17 \\
\hline & Okra & 27.53 & 6.61 & 17.62 & 0.19 & 2.75 \\
\hline & Yard long bean & 14.87 & 2.23 & 11.36 & 0.14 & 0.85 \\
\hline & Ash Gourd & 19.35 & 4.06 & 13.72 & 0.13 & 1.26 \\
\hline \multirow{5}{*}{ Winter } & Tomato & 28.44 & 8.53 & 15.64 & 0.15 & 2.14 \\
\hline & Chili & 20.36 & 6.72 & 11.99 & 0.45 & 5.73 \\
\hline & Bean & 12.67 & 3.17 & 7.98 & 0.09 & 1.17 \\
\hline & Bottle gourd & 19.16 & 5.94 & 10.73 & 0.13 & 1.53 \\
\hline & Radish & 27.49 & 4.95 & 20.56 & 0.06 & 1.10 \\
\hline \multirow{2}{*}{ Year round } & Green banana & 27.29 & 8.19 & 14.74 & 0.09 & 0.68 \\
\hline & Green papaya & 35.35 & 5.66 & 27.92 & 0.22 & 2.39 \\
\hline
\end{tabular}


Data furnished in Table II represented that green papaya, brinjal and tomato was the mostly produced homestead vegetables by the respondents in the study area. On an average the respondents produced $35.35 \mathrm{~kg}$ of green papaya and out of these they sold $27.92 \mathrm{~kg}$ in the market and earned money. Whereas the respondents produced $28.90 \mathrm{~kg}$ (average) of brinjal and out of these sold $11.16 \mathrm{~kg}$ at the rate of USD 0.12 into the local market. Meanwhile, they produced $28.44 \mathrm{~kg}$ of tomato and sold $15.64 \mathrm{~kg}$ of that in the market on an average. Other important vegetables of the study area were okra, green banana, radish, bitter gourd, and chili. After production, the respondents of the study area consumed these vegetables and also sold these in the market to earn some money as the production cost of these vegetables were low.

\section{Socioeconomic Impact of Homestead Vegetable Production}

The respondents of the study area were asked to provide their opinion on the socioeconomic impact of homestead vegetable production. Through this study, we identified a total number of eight impact statement. Accordingly, we collected the response from each statement. Then based on the average score, the socioeconomic impact of homestead vegetable production was arranged in rank order and displayed in Fig. 1 below:

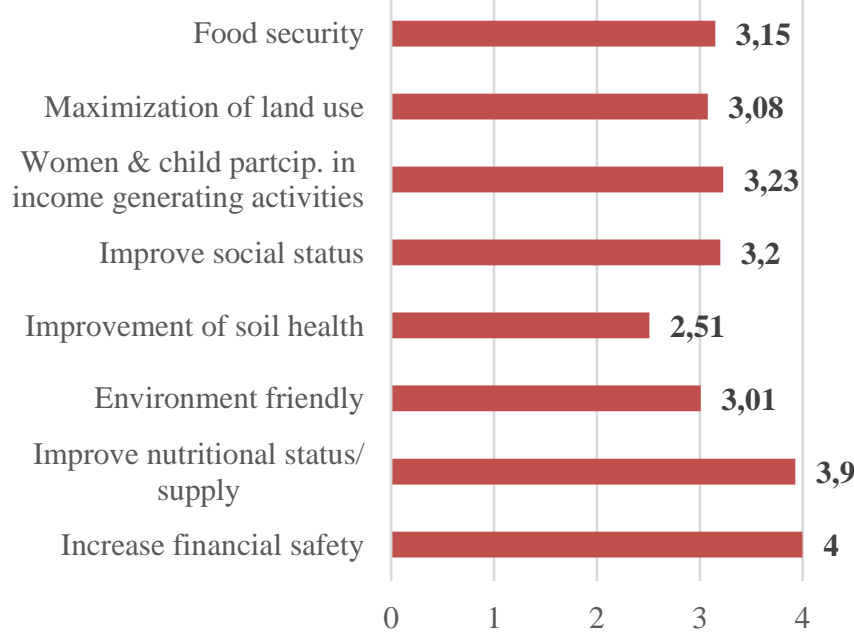

Fig. 1. Rank order of the socioeconomic impact of homestead vegetable production.

Based on the data furnished in Fig. 1 exhibited that the respondents of the study area thought that homestead vegetable production helped to 'increase financial safety' which was the topmost ranked impact (average score 04). Accordingly, production of homestead vegetables in the study area 'improve nutritional status' was the second highest impact (average score 3.93). Meanwhile. 'women \& child participation in income generating activities' was the third ranked impact of homestead vegetable production in the study area as it's average score was 3.23. On the other hand, 'improvement of soil health' was the lowest ranked impact (average was 2.51) of homestead vegetable production in the study area as it was a technical issue (statement) and the respondents might not have enough knowledge on this issue. Hence, from this Fig. 1 it was ascertained that the homestead vegetable production program in the study area provided some sorts of financial return/security which also had some socioeconomic impact on the vegetable growers. Study from [21] suggested that the standard of living of the rural poor will improve when they earn from different economic activities.

\section{Financial Security of the Respondents through Homestead Vegetable Production}

Individuals, households, and communities' financial security refers to their ability to meet their basic necessities in a sustainable and dignified manner. This varies depending on an individual's physical requirements, the surrounding environment, and cultural norms. Financial stability promotes tolerance, happiness, growth, and development.

For this specific research purpose, the income of the respondents solely from homestead vegetable production was collected and was treated as the financial security of the respondents of the study area. The income from homestead vegetable production was ranged from USD 0 to USD 86.25 with an average of USD 49.28. The respondents were classified into four categories based on their income from homestead vegetable as shown in Fig. 2.

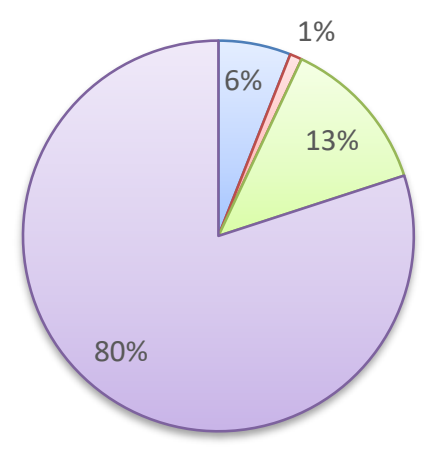

$\square$ No income $\square<12$ USD $\square 12.1-25$ USD $\square>25$ USD

Fig. 2. Distribution of the respondents according to their income from homestead vegetable gardening.

Data contained in Fig. 2 exhibited that the highest proportion of the respondents $(80 \%)$ belonged to more than USD 25 income category followed by USD 12.1-25 income category $(13.3 \%)$. This figure revealed that economic return from homestead gardening was not too much satisfactory. It might be due to small vegetable land ownership, lack of training received on vegetable production etc. So, they scarcely had the opportunity to go for commercial cultivation. Furthermore, use of old technology in vegetable production might be another reason for low economic return. [37], [38] found that home gardens contribute to income generation, improved livelihoods, and household economic welfare as well as promoting entrepreneurship and rural development.

\section{E. Attributes Influencing Respondents' Economic} Security of the Homestead Vegetable Production

To determine the attributes influencing the respondents' economic security of the homestead vegetable production, 10 independent variables were subjected to full-model regression analysis. In the full-model regression analysis, it was revealed that family size and homestead vegetable land ownership of the respondents were found to have significant influence (Table III). 
The model seems to have good fitness as indicated by $\mathrm{R}$ square. The coefficient of multiple determination, R2 was 0.629 for the model. This means that the explanatory variables in the model explained $62.9 \%$ of the variation in respondents' income from homestead vegetable production. The estimated result of the multiple regression analysis is satisfactory as it fulfils some of the criteria. Firstly, the adjusted R2 (which is the measure of goodness of fit of the estimated regression model) value of 0.587 indicates a good fitting of the model. The model also depicts that the F-test shows that the estimated regression is quite relevant which means dependent variable is related to each specified explanatory variable. The contributions of the selected factors on the respondents' economic security are discussed below:

TABLE III: INFLUENCE OF THE SELECTED CHARACTERISTICS OF THE RESPONDENTS WITH THEIR ECONOMIC SECURITY

\begin{tabular}{|c|c|c|c|c|c|}
\hline $\begin{array}{l}\text { Sl. } \\
\text { No. }\end{array}$ & Variables & $\begin{array}{c}\text { Estimated } \\
\text { Coefficient } \\
(\beta)\end{array}$ & SE & $\begin{array}{c}\mathrm{t}- \\
\text { value }\end{array}$ & $P$ \\
\hline 01. & Age & 0.190 & 1.260 & 0.263 & 0.793 \\
\hline 02. & $\begin{array}{l}\text { Educational } \\
\text { qualification }\end{array}$ & -0.602 & 1.680 & -1.144 & 0.256 \\
\hline 03. & Family size & $0.130 *$ & 0.006 & 1.862 & 0.066 \\
\hline 04. & $\begin{array}{l}\text { Agricultural } \\
\text { experience }\end{array}$ & -0.022 & 0.554 & -0.318 & 0.751 \\
\hline 05 & $\begin{array}{l}\text { Family annual } \\
\text { income }\end{array}$ & 0.024 & 0.381 & 0.301 & 0.764 \\
\hline 06. & $\begin{array}{l}\text { Time in home } \\
\text { gardening }\end{array}$ & 0.492 & 1.840 & 0.736 & 0.352 \\
\hline 07. & $\begin{array}{c}\text { Agricultural } \\
\text { Training Received }\end{array}$ & -0.073 & 0.460 & -1.039 & 0.302 \\
\hline 08. & $\begin{array}{c}\text { Extension } \\
\text { communication }\end{array}$ & 0.029 & 0.326 & 0.366 & 0.568 \\
\hline 09. & $\begin{array}{l}\text { Total land } \\
\text { ownership }\end{array}$ & 0.030 & 0.401 & 0.375 & 0.708 \\
\hline 10. & $\begin{array}{l}\text { Vegetable land } \\
\text { ownership }\end{array}$ & $0.760 * *$ & 0.301 & 1.543 & 0.007 \\
\hline
\end{tabular}

In regression analysis, family size showed a significant and positive influence on respondents' income from homestead vegetable production (Table IV). The value of regression coefficient (0.130) was significant at $10 \%$ level. That is with the increase of family size there will be increase in the income of the respondents from homestead vegetable production. The regression coefficient 0.130 implied that for every unit increase of family size there was a corresponding 0.130-unit increase in the income from homestead vegetable production of the respondents. Similar type of positive and significant contribution of family size was also observed by [28].

Alongside, we observed that the homestead vegetable land ownership of the respondents had a positive significant contribution on their income from homestead vegetable production as the computed ' $\beta$ ' value was 0.760 . This statement is significant at $1 \%$ level. The regression coefficient ' $\beta=0.760$ ' told us that the average value of income from homestead vegetable production increased by 0.760 times for one unit increase the homestead vegetable land ownership. That means if the ownership of homestead vegetable land could be increased among the local farmers, then their income from homestead vegetable production would also be positively changed. [24] also found that farm size had positive and significant relationship with increased income from pineapple cultivation in their respective study.

\section{CONCLUSIONS}

Based on the major findings and logical interpretation it is concluded that:

1. The respondents of the study area cultivated different types of vegetables in their homestead areas. Among different vegetables, green papaya, brinjal, tomato, green banana, okra, and radish were dominant. Out of the produced vegetables, the respondents consumed some vegetables and sold the rest part of the vegetables. The respondents earned money by selling these vegetables. While maintaining vegetable gardening, the respondents utilized different types of technology, namely, using balanced fertilizer as well as pheromone trap were the foremost. Moreover, the respondents believed that homestead vegetable gardening accelerated their socioeconomic status by means of increment of financial and food safety, increased income generating activities of women and so on.

2. Findings of the socio demographic characteristics of the respondents exhibited that half percentage of the respondents were more than 50 years of age who were mostly secondary level $(69 \%)$ educated, and on an average they had more than 18 years of agricultural experience. The findings of the study also suggested that $80 \%$ of the respondents had small to medium (4-6 members) family size who spent about 3 hours (average) for homestead vegetable gardening. Although the average total land holding of the respondents were 1.25 acre, but their average homestead vegetable land holdings were 0.17 acre, and these lands were utilized for producing different types of vegetables.

3. The respondents of the study area earned some amount of money by selling the vegetables into the market. On an average the respondents earned an amount of $3942 \mathrm{Tk}$ in a year by selling vegetables which were produced in their homestead areas. Moreover, $80 \%$ of them earned more than $2000 \mathrm{Tk}$ per year from homestead vegetable which revealed few amounts of economic return from homestead vegetable production. The findings from regression analysis depicted that among the selected characteristics of the respondents, family size and vegetable land ownership had significant contribution on the respondents' income from homestead vegetable production in the study area.

\section{ACKNOWLEDGMENT}

The authors would like to acknowledge Bangabandhu Sheikh Mujibur Rahman Agricultural University, specially the Department of Agricultural Extension \& Rural Development. We are also grateful to the farmers from whom data have been collected.

\section{REFERENCES}

[1] Ghosh, M. K., Hasan, S. S., Fariha, R., Bari, M. O. and Parvin, M. A. (2021). Women Empowerment through Agriculture in Chapainawabganj, Bangladesh. European Journal of Agriculture and Food Sciences, 3(1): 153-160. http://dx.doi.org/10.24018/ejfood.2021.3.1.235.

[2] Hasan, S. S., Turin, M. Z., Ghosh, M. K. and Khalil, M. I. (2017a) Assessing Agricultural Extension Professionals Opinion towards Sustainable Agriculture in Bangladesh. Asian Journal of Agricultural Extension, Economics and Sociology, 17(1): 1-13. http://dx.doi.org/10.9734/AJAEES/2017/33338. 
[3] Hasan, S. S. and Sultana, S. (2011). Food and Economic Security through Homestead Vegetable Production by Women in Flood Affected "Char" Land. The Agriculturists, 9(1\&2): 44-53.

[4] BBS. (2018). Yearbook of Agricultural Statistics. Dhaka: Ministry of Planning, Government of the people's Republic of Bangladesh.

[5] BBS. (2016). Yearbook of Agricultural Statistics. Dhaka: Ministry of Planning, Government of the people's Republic of Bangladesh.

[6] Asaduzzaman, M., Naseem, A. and Singla, R. (2011). Benefit-cost assessment of different homestead vegetable gardening on improving household food and nutrition security in rural Bangladesh. Agricultura and Applied Economics Association's 2011 AAEA and NAREA Joint Annual Meeting, Pittsburgh, Pennsylvania.

[7] Abedin, M. Z. and Quddus, M. A. (1990). Household fuel situation, home gardens and agroforestry practice at six agro-ecologically different locations of Bangladesh. In M. Z. Abedin, C. K. Lai, and M. O. Ali (Eds.), Homestead plantation and agroforestry in Bangladesh (pp. 19-53). Bangladesh: BARI.

[8] Brierley, J. S. (1985). West Indian kitchen gardens: a historical perspective with current insights from Grenada. Food and Nutrition Bulletin, 7(3): 1-10.

[9] Ferdous, Z., Datta, A., Anal, A. K., Anwar, M. and Khan, A. M. R. (2016). Development of home garden model for year round production and consumption for improving resource-poor household food security in Bangladesh. Wageningen Journal of Life Sciences, 78: 103-110.

[10] Ali, A. M. S. (2005). Home gardens in smallholder farming systems: examples from Bangladesh. Human Ecology, 33(2): 245-270.

[11] Galhena, D. H., Freed, R. and Maredia, K. M. (2013). Home gardens: a promising approach to enhance household food security and wellbeing. Agriculture and food security, 2(1): 8

[12] Talukder, A., Kiess, L., Huq, N., De Pee, S., Darnton-Hill, I. and Bloem, M. W. (2000). Increasing the production and consumption of vitamin A-rich fruits and vegetables: Lessons learned in taking the Bangladesh homestead gardening programme to a national scale. Food and Nutrition Bulletin, 21(2): 165-172.

[13] Hossain, M. A. and Hasan, S. S. (2018). Potentiality of Underutilized Vegetables for Contribution to Sustainable Development Goals (SDGs) in Bangladesh. Asian Journal of Agricultural Extension, Economics \& Sociology, 26(2): 1-9.

[14] Cabalda, A. B., Rayco-Solon, P., Solon, J. A. A. and Solon, F. S. (2011). Home gardening is associated with Filipino preschool children's dietary diversity. Journal of the American Dietetic Association, 111(5): 711-715.

[15] Weinberger, K. (2013). Home and community gardens in Southeas Asia: potential and opportunities for contributing to nutrition-sensitive food systems. Food security, 5(6): 847-856.

[16] Chakraborty, S. and Basu, D. (2018). Homestead Gardening: An Emerging Venture Towards Achieving Food Security and Nutritiona Security-A Study of Selected Areas of West Bengal. International Journal of Applied and Natural Sciences, 7(1):49-62.

[17] Dey, S., Sarker, U. K. and Awal, M. A. (2012). Year round homestead vegetables production: reduction of nutritional deficiency and income generation for small households. Bangladesh Journal of Progressive Science and Technology, 10(2): 187-190.

[18] Bushamuka, V. N., de Pee, S., Talukder, A., Kiess, L., Panagides, D., Taher, A. and Bloem, M. (2005). Impact of a homestead gardening program on household food security and empowerment of women in Bangladesh. Food and nutrition bulletin, 26(1): 17-25

[19] Schreinemachers, P., Patalagsa, M. A. and Uddin, N. (2016). Impact and cost-effectiveness of women's training in home gardening and nutrition in Bangladesh. Journal of Development Effectiveness, 8(4), 473-488.

[20] Al-Mamun, M. H., Bashar, H. M. K., Islam, M. S., Howlader, M. H. K. and Hasan, M. S. (2010). A case study on homestead vegetables cultivation: Food security and income. International Journal of Sustainable Crop Production, 5(1): 5-10.
[21] Hasan S. S, Ghosh, M. K., Arefin, M. S. and Sultana, S. (2015a) Farmers' Attitude Towards Using Agro-Chemicals in Rice Production A Case in Laxmipur District of Bangladesh. The Agriculturists, 13(2): 105 .

[22] Salawat, N., Hasan, S. S., Khan, A. S., Rahman, M. S., Hoque, M. M and Moonmoon, M. (2013). Study on knowledge and attitude of mushroom growers at selected upazilas of Dhaka. Bangladesh Journal of Mushroom, 7(1): 49-57.

[23] Saha, S., Hasan, S. S., Haque, M. E. and Ahamed, T. (2021). Perception Based Assessment of Ecosystem Services of Madhupur Sal Forest in Bangladesh. European Journal of Agriculture and Food Sciences, 3(1): 39-44.

[24] Hasan, S. S., Ali, M. A. and Khalil, M. I. (2010). Impact of pineapple cultivation on the increased income of pineapple growers. The Agriculturists, 8(2): 50-56.

[25] Hasan, S. S., Mohammad, A., Ghosh, M. K. and Khalil, M. I. (2017b) Assessing of farmers' opinion towards floating agriculture as a means of cleaner production: A case of Barisal district, Bangladesh. Current Journal of Applied Science and Technology, 20 (6): 1-14.

[26] Hasan, S. S., Hossain, M., Sultana, S. and Ghosh, M. K. (2015b) Women's involvement in income generating activities and their opinion about its contribution: A study of Gazipur District, Bangladesh. Science Innovation, 3(6): 72-80.

[27] Ghosh, M. K., Hasan, S. S., Haque, M. E. and Uddin, M. J. (2020) Knowledge of farmers to sustainable agriculture practices: A case study in Southwestern region of Bangladesh," Scholars Journal of Agriculture and Veterinary Sciences, 2020. http://dx.doi.org/10.36347/sjavs.2020.v07i01.002.

[28] Hasan, S. S., Roy, S., Saha, S. and Hoque, M. Z. (2021). Assessment of the Farmers' Perception on Vermicompost as Waste Management Practice and Economic Return in Some Areas of Bangladesh European Journal of Agriculture and Food Sciences, 3(3): 14-20. http://dx.doi.org/10.24018/ejfood.2021.3.3.287.

[29] Kafle, B. and Shah, P. (2012). Adoption of Improved Potato Varieties in Nepal: A case of Bara district. Journal of Agricultural Sciences, 7(1), 14-20.

[30] Mugisha, J., Ogwal-o, R., Ekere, W. and Ekiyar, V. (2004). Adoption of IPM groundnut production technologies in Eastern Uganda. African crop science journal, 12(4): 383-391.

[31] Ghosh, M. K. and Hasan, S. S. (2013). Farmers' attitude towards sustainable agricultural practices. Bangladesh Research Publications Journal, 8(4): 227-235.

[32] HIS (Household Income and Expenditure Survey). (2016). Bangladesh Bureau of Statistics. Statistics Division, Ministry of Planning, Dhaka.

[33] Hasan, S. S., Sultana, S. and Haque, M. E. (2007). Participation of rural women inhomestead vegetable production program. Journal of Innovation and Development Strategies, 1(1): 18-22.

[34] Haque, M. E., Hasan, S. S. and Sarker, A. (2006). Gender participation in Cauliflower seed production at Sadar upazila of Tangail district in Bangladesh. Journal of Agriculture and Rural Development, 4(1\&2): 169-174.

[35] Iftekhar, M. S. and Takama, T. (2008). Perceptions of biodiversity, environmental services, and conservation of planted mangroves: a case study on Nijhum Dwip Island, Bangladesh. Wetlands Ecology and Management, 16(2): 119-137.

[36] DAE. (2018). Agricultural Extension Manual. Dhaka: Department of Agricultural Extension.

[37] Calvet-Mir, L., Gómez-Baggethun, E. and Reyes-García, V. (2012). Beyond food production: Ecosystem services provided by home gardens. A case study in Vall Fosca, Catalan Pyrenees, Northeastern Spain. Ecological Economics, 74: 153-160.

[38] Trinh, L. N., Watson, J. W., Hue, N. N., De, N. N., Minh, N. V., Chu, P. and Eyzaguirre, P. B. (2003). Agrobiodiversity conservation and development in Vietnamese home gardens. Agriculture, Ecosystems and Environment, 97(1-3): 317-344. 